\title{
Pemikiran Politik Perempuan Nahdlatul Ulama (NU) dalam Perspektif Feminisme: Penelusuran Pemikiran Mainstream dan Non-Mainstream
}

\author{
Linda Dwi Eriyanti
}

\begin{abstract}
This study aims to identify the appropriate perspective to describe non-mainstream feminist political thought of NU women. The authors found that political thought of NU women were categorized into the mainstream and non-mainstream thinking. Thought mainstream covers many of the issues associated with formal politics of women, gender equality, as well as sexuality. Mainstream thinkers give prescriptions on such issues through formal state politics and in public areas. While the women's non-mainstream political thought, although identifying the source and impact of the oppression of women is equal to mainstream thinking, they leave notes and analysis of different approaches. This study attempts to framing NU diverse political thought through the four schools of feminism, the liberal feminism, marxist feminism, socialist feminism and radical feminism. This study found that the ideas of radical feminism turned out to give space to the explanation of political thought NU women's non-mainstream, where they tend to emerge from the lower classes, and not formally organized.
\end{abstract}

\section{Keywords:}

political thought; NU Women; mainstream; non-mainstream.

\begin{abstract}
Abstrak
Studi ini bertujuan untuk mengidentifikasi perspektif feminis yang sesuai untuk mendeskripsikan pemikiran politik perempuan NU non-mainstream. Penulis menemukan bahwa selama ini ada pemikiran politik perempuan NU yang dikategorikan menjadi pemikiran mainstream dan nonmainstream. Pemikiran mainstream melingkupi banyak isu yang terkait dengan politik formal perempuan, kesetaraan gender, juga seksualitas. Pemikir-pemikir mainstream memberikan preskripsi atas isu-isu tersebut melalui politik formal kenegaraan dan di wilayah publik. Sedangkan pemikiran politik perempuan non-mainstream, meski mengidentifikasi sumber dan dampak opresi terhadap perempuan sama dengan pemikiran mainstream, mereka memberikan catatan analisis dan pendekatan yang berbeda. Studi ini mencoba mengkerangkai ragam pemikiran politik NU tersebut melalui empat aliran feminis, yakni feminis Liberal, feminis Marxis, feminis Sosialis, dan feminis Radikal. Hasil penelitian ini menemukan bahwa ide-ide di dalam feminis radikal ternyata lebih banyak memberikan ruang dalam menjelaskan fenomena pemikiran-pemikiran politik perempuan NU non-mainstream, di mana mereka cenderung muncul dari kalangan bawah, dan tidak terorganisir secara formal.
\end{abstract}

\section{Kata Kunci:}

pemikiran politik; perempuan NU; mainstream; non-mainstream.

\footnotetext{
- Staff Pengajar Jurusan Hubungan Internasional Universitas Jember

Email: elindadwi@yahoo.com
} 


\section{Pendahuluan}

Pemikiran politik perempuan NU saat ini semakin banyak menjadi rujukan banyak aktivis perempuan muslim di Indonesia. Pemikiran-pemikiran tersebut kemudian menjadi arus utama atau mainstream, yakni pemikiran yang paling banyak berpengaruh dan memiliki banyak pengikut. Pemikiranpemikiran tersebut bisa menjadi arus utama setelah disebarkan melalui karya-karya berupa buku dan karya publikasi lain.

Pemikiran politik perempuan yang mainstream melingkupi pemikiran tentang politik formal kesetaraan dan keadilan gender, serta seksualitas. Pemikiran politik formal diantaranya terkait dengan perlunya perempuan terlibat dalam politik praktis, di partai politik, di lembaga politik, parlemen, dan menjadi pejabat publik. Pemikiran kesetaraan dan keadilan gender tentang relasi antara perempuan dan laki-laki, meliputi kesetaraan dan keadilan di ruang publik sampai ke wilayah privat. Di ruang publik perempuan menginginkan terwujudnya status dan hak yang sama; sedangkan di wilayah privat, menginginkan adanya tanggungjawab dan posisi yang setara dalam pengambilan keputusan penting. Pemikiran tentang seksualitas dan kebertubuhan perempuan yang mainstream terkait dengan hak perempuan atas kesehatan reproduksi, penentangan poligami, legalisasi aborsi, dan menolak pornografi.

\section{Pemikiran Politik Perempuan NU Mainstream}

Pemikiran politik perempuan NU dikenal melalui pendapat dan tulisan-tulisan dari perempuan NU sendiri, seperti yang dilakukan oleh Shinta Nuriyah Wahid, Siti Musdah Mulia, Maria Ulfah Anshor, Khofifah Indar Parawansa, Lily Zakiyah Munir, dan Aisyah Hamid Baidlowi. Karya yang berupa buku-buku tersebut semuanya mewakili pemikiran yang mainstream.
Shinta Nuriyah Wahid, salah satu tokoh perempuan NU, yang juga istri $\mathrm{KH}$ Abdurrahman Wahid, memunculkan pemikiran bahwa ketimpangan gender bersumber dari relasi yang dibangun dalam keluarga. Shinta menganggap ketidakadilan yang dialami perempuan disebabkan oleh ajaran agama misoginis yang dianggap sebagai kebenaran mutlak. Ajaran ini telah melestarikan ideologi patriarki yang memang dikembangkan untuk mempertahankan dominasi laki-laki terhadap perempuan. Bersama Forum Kajian Kitab Kuning (FK3), Shinta menulis buku "Wajah Baru Relasi Suami-Istri: Telaah Kitab Uqud al-Lujjayn" yang berisi interpretasi ulang atas kitab Uqud al-Lujjayn yang ditulis oleh Muhammad Ibn Umar al-Banten al-Jawy pada tahun 1877. Kitab 'Uqud al-Lujjayn membahas hak dan tanggung jawab suami-istri yang dinilai misoginis terhadap perempuan. Dari 90 hadis dalam Uqud alLujjayn ternyata 50 di antaranya bermasalah, ada sembilan hadis di antaranya palsu dan 21 hadist hampir palsu atau tidak ada sandarannya (Nuriyah dkk, 2001: 12).

Tokoh perempuan NU yang lain, Aisyah Hamid Baidlowi dikenal dengan pemikirannya tentang kesetaraan gender di ruang publik. Dalam karyanya yang berjudul "Peran dan Tanggungjawab dalam Pemberdayaan Kaum Perempuan", dibahas masalah kesenjangan pendidikan antara laki-laki dan perempuan, yang seharusnya tidak terjadi mengingat ada hadis yang menegaskan kesetaraan hak antara laki-laki dan perempuan untuk mencari ilmu (Munir, 1999: 126). Pendidikan penting untuk perbaikan kehidupan perempuan, termasuk dalam upaya mewujudkan kesejahteraan keluarga. Di bidang ekonomi, perempuan juga didorong untuk menjadi kekuatan ekonomi dengan membentuk koperasi dan melakukan kegiatan ekonomi modern. Sementara di bidang politik, perempuan juga diharapkan untuk meningkatkan partisipasinya, bukan hanya sebagai peserta pemilu, tetapi juga sebagai wakil rakyat (Munir, 1999: 130). 
Lyli Zakiyah Munir, dalam buku berjudul "Hak Azasi Perempuan dalam Islam: Antara Idealisme dan Realitas", menegaskan pemikiran bahwa budaya patriarki telah menempatkan perempuan hanya sebagai pelengkap, sebagai pendamping suami, hal ini bertentangan dengan Islam yang menyatakan hubungan laki-laki dan perempuan adalah setara dan resiprokal. Menurut Lyli, Islam tidak membebani perempuan dengan kewajiban di sektor produksi, tetapi lebih kepada tugas reproduksi. Peran ini menurutnya lebih penting karena hal ini merupakan penentu kualitas hidup manusia selanjutnya. Namun demikian tidak menutup kemungkinan atas pilihan perempuan untuk bekerja di sektor produktif dan kemasyarakatan atas kerelaan dirinya sendiri (Munir, 1999: 53-55).

Khofifah Indar Parawansa adalah salah satu tokoh perempuan NU yang dikenal dengan pemikirannya tentang kesetaraan gender dan partisipasi perempuan dalam politik formal. Pemikiran tentang kesetaraan gender secara khusus muncul dalam bukunya yang berjudul "Mengukur Paradigma Menembus Tradisi: Pemikiran Tentang Keserasian Jender". Untuk mewujudkan kesetaraan laki-laki dan perempuan, keadilan sosial dan penjaminan HAM, diperlukan perbaikan kualitas, status, dan peran perempuan dalam pembangunan untuk meningkatkan keadilan sosial dan hak-hak asasi manusia yang setara antara perempuan dan laki-laki. Menurutnya, kualitas perempuan penting untuk mendukung pembangunan di Indonesia. Di sisi lain, upaya peningkatan kualitas perempuan terhalang dengan pendekatan pembangunan yang mengabaikan keserasian dan keadilan gender. Oleh karenanya perlu reorientasi pembangunan yang mengarah kepada keserasian dan keadilan gender (Parawansa, 2006).

Tentang Politik Formal, dalam artikel "Hambatan terhadap Partisipasi Politik Perempuan di Indonesia", Khofifah mengidentifikasi faktor-faktor yang menghambat perempuan untuk berperan dalam politik, yakni: (1) budaya patriarki yang menentukan arena politik adalah untuk laki-laki, (2) proses seleksi dalam partai yang hanya dilakukan oleh elite partai yang mayoritas laki-laki, (3) media yang belum berpihak pada perempuan, (4) Kurangnya jaringan antar organisasi massa, LSM, dan partai politik untuk memperjuangkan representasi perempuan, (5) kemiskinan dan rendahnya tingkat pendidikan perempuan, (6) faktor keluarga yang menghambat aktivitas politik perempuan (Parawansa, 2002). Sejalan dengan pemikiran tersebut, dalam buku “NU, Perempuan, Indonesia, Sudut Pandang Islam Tradisional", Khofifah menegaskan perlunya perempuan NU menyebar dan menggeluti berbagai profesi di ruang publik untuk bisa membantu menyelesaikan masalah yang dihadapi bangsa Indonesia. Khofifah mencontohkan perlu perempuan NU menjadi dokter, untuk mengatasi masalah tingginya Angka Kematian Ibu (AKI) dan balita di Indonesia. (Parawansa, 2015). Khofifah juga berpikir bahwa perempuan layak menjadi pemimpin. Dalambuku "Memimpin Melayani”, Khofifah menegaskan bahwa dengan latar belakang keberagaman di Indonesia, lakilaki dan perempuan mempunyai hak dan peluang yang sama untuk menjadi pemimpin di tingkat lokal maupun nasional. Diperlukan keterbukaan dan dukungan dari berbagai pihak, termasuk pimpinan organisasi dan tokoh masyarakat untuk mendorong perempuan agar bisa menjadi pemimpin (Parawansa, 2015).

Tokoh Perempuan NU yang lain, Siti Musdah Mulia dikenal dengan pemikiranpemikiran yang radikal seputar isu kesetaraan gender, seksualitas dan politik perempuan. Buku "Muslimah Reformis: Perempuan Baru Keagamaan", mengungkap pemikiran Musdah Mulia tentang kesetaraan gender, yang mendorong perempuan untuk bangkit melawan hegemoni tafsir agama yang bias gender dan patriarkis karena dibuat oleh 
laki-laki. Perempuan seharusnya menjadi pembaru keagamaan untuk mewujudkan Islam yang ramah perempuan dan peduli kepada masalah-masalah kemanusiaan. Musdah Mulia menawarkan sepuluh reformasi keagamaan yang harus dilakukan oleh perempuan muslim, yakni: (1) menghayati Islam sebagai landasan reformasi, berikut prinsip kesetaraan dan keadilan bagi semua orang, (2) perempuan harus merebut posisi sebagai ulama, (3) perempuan harus melawan kekerasan, (4) perempuan harus menjadi pembela HAM, (5) perempuan harus menjadi pemimpin politik, (6) perempuan harus menjadi pelaku rekonsiliasi konflik, (7) perempuan harus kritis terhadap kebijakan publik, (8) perempuan harus peduli anak, (9) perempuan harus mampu memberi solusi atas persoalan masyarakat, (10) perempuan harus berani mengusung tafsir baru yang humanis, pluralis, demokratis untuk diterapkan dalam kehidupan sehari-hari (Mulia, 2005).

Selanjutnya dalam buku "Islam dan Inspirasi Kesetaraan Gender", Mulia mengungkapkan bahwa Islam adalah agama yang mengajarkan penghormatan dan pemuliaan terhadap manusia, tanpa mellihat jenis kelamin, gender, suku, ras, dan ikatan primordial lainnya. Mulia menekankan pentingnya pembaruan hukum Islam yang perspektif kesetaraan gender di Indonesia. Perlunya revisi Undang-Undang perkawinan yang dinilai tidak adil terhadap perempuan yang berarti juga bertentangan dengan implementasi HAM dan demokrasi. Musdah Mulia juga mempertanyakan pelaksanaan demokrasi di Indonesia dengan maraknya Perda Syariat yang jelas-jelas diskriminatif terhadap perempuan (Mulia, 2006). Buku "Membangun Surga Di Bumi, Kiat-Kiat Membina Keluarga Ideal Dalam Islam", mengungkapkan gagasan Musdah Mulia tentang perkawinan dan kehidupan keluarga menurut hukum Islam. Dalam buku ini, ia menyebutkan lima prinsip dasar pernikahan, yakni prinsip ikatan yang kuat, sayang dan tenggang rasa, hubungan yang makruf, kesetaraan, dan monogami (Mulia, 2012:16-19). Selain itu, ia juga menegaskan dukungannya terhadap nikah beda agama, penghormatan hak seksual kaum gay dan lesbi, hak reproduksi perempuan, serta penentangannya terhadap poligami (Mulia, 2012).

Musdah Mulia membahas lebih mendetail kedudukan dan posisi perempuan dalam Islam pada buku berjudul "Kemuliaan Perempuan Dalam Islam". Perempuan adalah makhluk yang memiliki harkat dan martabat sama seperti halnya laki-laki. Perempuan dan laki-laki diciptakan dari unsur yang satu (nafs wahidah), dimana keduanya diciptakan untuk menjadi pemimpin untuk mengelola kehidupan di bumi. Laki-laki dan perempuan dibebani tugas yang sama, yakni amar ma'ruf nahi mungkar, untuk mewujudkan masyarakat yang sejahtera, damai, bahagia dalam ridha Allah Swt. Islam menolak semua bentuk ketimpangan dan ketidakadilan, serta mendorong umatnya untuk menghapuskan bentuk-bentuk diskriminasi, eksploitasi dan kekerasan terhadap perempuan (Mulia 2014).

Masih tentang isu kesetaraan, pemikiran Musdah Mulia dalam buku "Islam dan Hak Asasi Manusia: Konsep dan Implementasi", melingkupi semangat multikulturalisme Indonesia. Musdah Mulia menekankan konsep HAM seharusnya berlaku untuk semua manusia tanpa membedakan ras, warna kulit, jenis kelamin, suku bangsa, bahasa, maupun agamanya. Dalam Islam, rumusan HAM telah ada dalam Piagam Madinah yang didalamnya meliputi prinsip persaudaraan, prinsip saling menolong, prinsip melindungi yang lemah dan teraniaya, prinsip saling menasehati, dan prinsip kebebasan beragama. Dengan mengutip rumusan tujuan dasar syariat Islam dari Imam Al Ghazali, Musdah Mulia berargumen bahwa Islam akomodotif terhadap kemaslahatan manusia, dengan menjamin (1) hak kelangsungan hidup (hifz al-nafs), (2) 
hak kebebasan beropini dan berekspresi (hifz al-aql), (3) hak kebebasan beragama (hifz addin), (4) hak dan kesehatan reproduksi (hifz an-nasl), (5) hak property (hifz al-maal) meliputi hak-hak atas pekerjaan dan upah yang layak dan memperoleh jaminan perlindungan dan kesejahteraan (Mulia, 2010).

Tentang isu seksualitas, Musdah Mulia dalam buku "Islam Menggugat Poligami", menegaskan penolakannya atas poligami. Poligami merupakan bentuk superioritas lakilaki yang menempatkan perempuan sebagai pelengkap dan hanya dimanfaatkan untuk kepentingan laki-laki. Pemahaman misoginis terhadap teks agama menempatkan perempuan pada posisi yang tidak menguntungkan, melahirkan berbagai bentuk penindasan, pelecehan seksual, dan berbagai bentuk tindakan kekerasan lain. Oleh karena itu, perlu reintepretasi pemahaman ajaran agama yang lebih adil gender (Mulia, 2004). Seksualitas adalah sebuah proses sosial yang menciptakan dan mengarahkan hasrat atau berahi. Seksualitas seharusnya merupakan hal yang independen dan menjadi hak semua orang, termasuk perempuan. Perempuan mempunyai hak dan kebebasan atas tubuhnya sendiri, berhak atas kesehatan dan kenikmatan tubuhnya, juga untuk mengapresiasi dan mengekspresikan tubuhnya sendiri. Namun kenyataannya, seksualitas selalu dipahami dalam konteks maskulinitas, menempatkan laki-laki sebagai subyek dan perempuan sebagai obyek. Pandangan ini melegitimasi laki-laki melakukan pelecehan, perkosaan, dan kekerasan seksual. Masih tentang seksualitas, dengan merujuk ayat-ayat Al-Qur'an soal hidup berpasangan (QS. Ar-Rum: 21, QS. AzZariyat: 49, dan QS. Yasin: 36), Musdah Mulia menafsirkan bahwa berpasangan itu tidak harus dalam konteks hetero, tetapi bisa homo dan bisa lesbian (Jurnal Perempuan, 2008).

Pemikiran tentang politik formal Musdah Mulia bisa ditemukan di buku "Perempuan dan Politik". Musdah Mulia menganggap perempuan harus masuk ke politik formal dengan membawa warna baru, karena perempuan memaknai kekuasaan secara berbeda dari laki-laki. Kekuasaan oleh perempuan, yakni kekuasaan dengan kasih sayang dan kelembutan bisa diarahkan untuk mencapai tujuan bersama. Jadi perempuan dapat menjadi politikus yang tidak menyakiti lawan politiknya, mampu mengasah sisi keibuan untuk tanggap terhadap kebutuhan orang lain, dan memberdayakan orang lain(Mulia, 2005:1213). Laki-laki dan perempuan merupakan makhluk yang setara, perempuan boleh menjadi pemimpin, dan Islam menjamin hakhak politik perempuan. Mulia memberikan solusi untuk meningkatkan partisipasi politik perempuan, yakni melalui pembongkaran terhadap mitos yang menghambat partisipasi politik perempuan, mengkritisi penafsiran agama yang bias gender dan mengatasi hambatan pemahaman agama yang lebih adil gender, juga dengan berupaya mengubah kebijakan publik yang tidak adil (Mulia, 2005).

Selanjutnya, dalam buku "Menuju Kemandirian Politik Perempuan: Upaya Mengakhiri Depolitisasi Perempuan Di Indonesia", Musdah Mulia sekali lagi menegaskan pentingnya perempuan berpartisipasi dalam politik formal di Indonesia. Telah terjadi proses depolitisasi terhadap perempuan, yang berdampak pada ketidakpahaman perempuan akan pentingnya politik bagi perbaikan kehidupan perempuan. Anggapan bahwa politik adalah wilayah laki-laki, yang digambarkan sebagai hal yang maskulin, kotor dan kejam membuat perempuan enggan terlibat didalamnya. Perlu dilakukan instropeksi, dan evaluasi dari semua pihak agar masyarakat menyadari adanya ketimpangan gender dan ketidakadilan sosial dalam kehidupan politik di Indonesia (Mulia, 2008).

Musdah Mulia sangat mendukung kepemimpinan perempuan. Dalam buku 
“Muslimah Sejati: Menempuh Jalan Islami Meraih Ridha Ilahi", Mulia menegaskan argumen yang memperbolehkan kerjasama laki-laki dengan perempuan, untuk kebaikan, termasuk dengan memberikan nasihat atau kritik kepada penguasa. Perempuan memiliki hak yang sama dengan laki-laki dalam mengatur kepentingan umum, dalam melakukan kebaikan dan mencegah dari kemungkaran. Perempuan punya hak untuk menduduki seluruh jabatan politik, termasuk menjadi pemimpin negara. Tidak ada ketentuan agama yang melarang keterlibatan perempuan dalam politik, sebaliknya justru banyak ayat dan hadis yang dapat dijadikan argumen dasar untuk menetapkan adanya hak-hak perempuan di bidang politik. Hanya saja yang menjadi permasalahan adalah intepretasi yang mengabaikan semangat moral Al-Quran dan bias patriarki (Mulia, 2011).

Maria Ulfah Anshor, Tokoh Perempuan NU yang pernah menjadi Ketua Umum Fatayat NU selama dua periode, memunculkan pemikiran-pemikiran terkait isu partisipasi politik perempuan dan seksualitas. Dalam buku "Nalar Politik Perempuan Pesantren", ia mengulas perkembangan sejarah partisipasi politik formal perempuan sejak era sebelum 1928 sampai dengan terbentuknya produk hukum yang menjamin kuota keterwakilan perempuan 30 persen. Disebutkannya sejak Pemilu tahun 1955 hingga 2004, telah 9 kali perempuan ikut dalam pemilu, tetapi keterwakilan mereka tidak lebih dari 12 persen (Anshor, 2006: 49). Hambatan struktural maupun kultural untuk memasuki politik formal sangat merugikan perempuan. Oleh karena itu penting adanya pengarusutamaan gender di Indonesia, disamping upaya peningkatan kesadaran kritis bagi perempuan sendiri (Anshor, 2006:5859). Maria Ulfah menilai penting partisipasi politik formal perempuan, karena ada agenda mendesak yang membutuhkan sensitifitas gender dalam pengambilan keputusan terkait dengan upaya mengatasi masalah perlindungan hukum bagi TKI, ancaman HIV/ AIDS, penguatan hak reproduksi perempuan, maraknya pornografi, poligami, dan politik yang seringkali tidak berpihak kepada kelompok yang lemah. Permasalahan tersebut bukan hanya membutuhkan fikih alternatif tetapi juga produk perundang-undangan resmi dari negara yang melindungi secara legal.

Pemikiran Maria Ulfah Anshor yang sampai saat ini masih menjadi perdebatan di kalangan kaum ulama Indonesia adalah tentang legalisasi aborsi. Dalam buku "Fikih Aborsi, Wacana Penguatan Hak Reproduksi Perempuan", Maria Ulfah menguraikan konsep tentang penciptaan manusia, dan memberikan fakta seputar aborsi yang terjadi di Indonesia, bahwa 60-99,9 persen pelaku aborsi di Indonesia adalah perempuan yang telah menikah (Anshor, 2006: 47). Maria Ulfah membedah perdebatan ulama terkait dengan aborsi, dan menunjukkan bahwa aborsi adalah masalah serius yang bukan hanya berhubungan dengan nyawa, tetapi juga dengan kondisi kejiwaan dan keberlangsungan hidup di masa depan (Anshor, 2006:115). Selain dari sudut pandang Islam, Maria juga melihat dari sudut pandang agama Yahudi, agama Kristen dan Katholik, juga Hindu dan Budha, yang kesemuanya sampai kepada kesimpulan bahwa dengan alasan tertentu aborsi diperbolehkan. Dengan mempertimbangkan faktor penentu kehamilan tidak diinginkan, kaidah fikih serta pertumbuhan embrio, Maria Ulfah menegaskan bahwa pengguguran kandungan yang aman menurut fikih adalah setelah terjadi kehamilan hingga kehamilan berusia delapan minggu atau usia janin enam minggu (Anshor, 2006: 187).

Pemikiran-pemikiran politik perempuan NU dalam karya-karya diatas melingkupi isu kesetaraan gender, seksualitas, dan partisipasi politik perempuan, yang kesemuanya adalah pemikiran yang mainstream di kalangan muslim Indonesia. Karya-karya diatas sama sekali tidak menyentuh pemikiran-pemikiran non- 
mainstream atau alternatif. Pemikiran mainstream dan non-mainstream melihat penyebab dan dampak opresi terhadap perempuan dengan cara yang sama namun mereka memberikan preskripsi yang berbeda. Pemikir mainstream selalu memberikan preskripsi atas segala dampak opresi perempuan melalui proses politik formal, dalam kerangka besar politik nasional dan melingkupi area publik.

\section{Menimbang Pemikiran Politik Perempuan NU Non-Mainstream}

Telah banyak pemikiran politik perempuan NU yang mainstream dan melingkupi banyak isu, namun demikian, kondisi perempuan NU pada tingkat bawah tidak banyak berubah. Mereka masih mengalami banyak ketertindasan dan ketidakadilan. Sistem patriarki hanya bisa menerima hubungan heteroseksualitas, yang didalam masyarakat kemudian dilegalkan dalam lembaga perkawinan. Dalam kehidupan perkawinan, perempuan seringkali hanya ditempatkan sebagai objek seks, karena seks hanya untuk kepentingan laki-laki. Dalam rumah tangga, perempuan ditempatkan pada posisi untuk bertanggungjawab penuh atas pekerjaan di dalam keluarga, dan pada kondisi tertentu, perempuan juga sekaligus menjadi pencari nafkah. Disisi lain, peluang kerja yang dimiliki perempuan di tingkat bawah terbatas. Mereka yang dianggap memiliki kompetensi rendah hanya bisa mengakses jenis-jenis pekerjaan tertentu dengan upah rendah. Perempuan juga mengalami berbagai bentuk kekerasan yang dilakukan oleh lakilaki, di ranah publik, juga di ranah privat yang seringkali dianggap sebagai tempat teraman bagi perempuan. Sedangkan masyarakat cenderung permisif terhadap tindak kekerasan yang dilakukan oleh laki-laki, bahkan dengan alasan tertentu, perempuan dianggap wajar menerima perlakuan tersebut. Cara hidup, perilaku dan sikap perempuan sehari-harinya ditentukan oleh patriarki yang dikonstruksi melalui agama, lembaga pendidikan, juga dari berbagai media yang ada di masyarakat. Kondisi ini diperparah oleh negara yang diskriminatif terhadap perempuan dengan mengeluarkan produk-produk kebijakan patriarki.

Diluar lingkaran elite dan kelembagaan perempuan NU diatas, ada pemikiran yang berbeda secara substansi, yang disebarkan tidak melalui lembaga-lembaga formal perempuan NU. Di forum-forum pengajian, arisan, dan forum aktivitas ekonomi perempuan NU tingkat bawah, bisa ditemukan pemikiran alternatif yang non-mainstream. Forum-forum tersebut menjadi ruang bagi perempuan NU di tingkat bawah untuk berdiskusi, mengaktualisasikan kepentingannya, sekaligus sebagai media ekspresi pemikiranpemikirannya. Peluang terbatas perempuan di ruang politik tergantikan dengan forum yang memberikan ruang untuk membangkitkan kesadaran menuju keberdayaan yang esensi bagi kehidupan mereka.

Perempuan NU di tingkat bawah dengan kompleksitas latarbelakangbudaya, pendidikan, dan tingkat ekonomi, memiliki pemikiran alternatif untuk mengatasi ketertindasan dan ketidakadilan yang masih terus dialaminya. Pemikiran untuk mengubah struktur yang menindas dalam keluarga, pemikiran untuk menggugat sistem ekonomi yang diskriminatif perempuan, pemikiran anti kekerasan dan pemikiran untuk menggugat patriarki yang membatasi gerak dan ekspresinya, bahkan terkait dengan seksualitas, bisa ditemui dalam forum-forum tersebut.

Perempuan di tingkat bawah berpikir bahwa struktur yang didominasi oleh lakilaki, baik dalam posisi sebagai ayah, ataupun sebagai suami dalam rumah tangga adalah salah dan perlu diubah. Sistem ekonomi yang dibangun pemerintah dan masyarakat patriarki tidak memberi tempat bagi perempuan tingkat bawah untuk membangun perekonomiannya. Meskipun perempuan ditingkat bawah 
terbiasa melakukan jenis-jenis pekerjaan yang sama dengan yang dilakukan oleh laki-laki, namun anggapan bahwa laki-laki adalah pencari nafkah utama bagi keluarga masih ada. Mereka lantas berpikir untuk berbagi beban atas pekerjaan-pekerjaan dalam rumah tangga yang selama ini dianggap sebagai tugas perempuan. Kekerasan yang dialami oleh perempuan, baik secara fisik maupun psikologis, telah memunculkan pemikiran untuk membongkar akar kekerasan, bahwa dengan alasan apapun, tidak ada yang boleh melakukan kekerasan terhadap orang lain. Bukan hanya kekerasan yang dilakukan oleh individu, yang kebanyakan pelakunya adalah laki-laki, tetapi juga kekerasan oleh perempuan lain, oleh institusi negara, maupun kekerasan oleh masyarakat. Pemikiran tentang kebebasan berekspresi bagi perempuan, termasuk yang terkait dengan seksualitasnya, muncul seiring dengan meningkatnya kesadaran akan otoritas perempuan atas tubuhnya. Mereka mulai berpikir bahwa perempuan berhak untuk memilih pasangan hidupnya, memilih untuk menikah atau tidak menikah, bahkan memilih untuk punya anak atau membatasi jumlah anak yang diinginkannya.

Di banyak tempat, pengajian dianggap sebagai forum yang wajib diikuti oleh perempuan NU, karena dianggap sebagai bagian dari tradisi yang harus ada dan dijaga keberlangsungannya sebagai bentuk eksistensi umat beragama. Tidak wajar jika ada perempuan yang mengaku NU tetapi tidak pernah mengikuti pengajian. Pengajian ada yang sengaja dibentuk berdasarkan struktur organisasi, seperti yang dilakukan oleh Fatayat NU dan Muslimat NU yang mengadakan pengajian di tiap ranting dan anak cabang yang ada di setiap kecamatan dan desa. Tetapi ada juga pengajian yang dibentuk karena adanya ikatan kekeluargaan, juga kelompok pengajian yang berdasarkan latar belakang profesi. Sedangkan arisan sengaja dibentuk sebagai forum pertemuan komunitas maupun antar keluarga. Arisan, bisa berupa arisan untuk pembelian barang tertentu maupun berupa pengumpulan uang yang diundi di tiap pertemuannya, forum ini menarik bagi perempuan NU di tingkat bawah sebagai forum yang memfasilitasi aktivitas mereka untuk menabung, atau mendapatkan kredit tanpa bunga bagi yang mendapat undian diawal. Forum ini juga menjadi sarana untuk mengkomunikasikan pemikiran-pemikiran perempuan NU di tingkat bawah, sekaligus menjadi model perlawanan terhadap sistem ekonomi yang mainstream seperti perbankan dan lembaga-lembaga keuangan lainnya. Forum-forum informal berbasis aktivitas perempuan biasanya berupa komunitas atau perkumpulan yang sifatnya tidak terorganisir secara resmi. Misalnya forum yang terbentuk di sekolah-sekolah dimana para perempuan NU mengantar dan menunggui anaknya yang bersekolah, di pasar saat berbelanja, maupun di tempat tetangga atau kerabat yang sedang hajatan.

Pemikiran mainstream dan nonmainstream melihat penyebab dan dampak opresi terhadap perempuan dengan cara yang sama namun mereka memberikan preskripsi yang berbeda. Pemikir mainstream selalu memberikan preskripsi atas segala dampak opresi perempuan melalui proses politik formal, dalam kerangka besar politik nasional dan melingkupi area publik. Sedangkan pemikiran politik perempuan non-mainstream memberikan preskripsi dengan cara berbeda, yakni melalui jalur-jalur informal, melingkupi aspek yang lebih diskursif dengan memaknai ulang relasi kuasa dalam rumah tangga. Preskripsi yang diberikan oleh pemikir-pemikir non-mainstream diyakini akan lebih efektif mengatasi ketertindasan yang dialami oleh perempuan tingkat bawah.

Pemikiran politik perempuan NU mainstream melingkupi banyak isu yang terkait dengan perbaikan hidup perempuan. Namun demikian, opresi yang dialami perempuan, yang 
sebenarnya tidak berasal dari struktur formal, tidak bisa terselesaikan dengan preskripsi yang ditawarkan oleh pemikiran mainstream. Oleh karena itu perlu adanya penelitian yang mendalam mengenai pemikiran politik perempuan NU non-mainstream, yang disertai dengan pengungkapan adanya kontestasi antara dua tradisi berpikir tersebut. Pemikiran politik perempuan NU di tingkat lokal, dengan sudut pandang politik informal untuk menemukan sesuatu khas dan berbeda, yang bisa jadi dipengaruhi oleh kultur tertentu, suku tertentu, bahkan lokalitas itu sendiri. Melihat politik dari pengajian-pengajian, arisan, dan forum-forum aktivitas ekonomi perempuan NU adalah sesuatu yang baru dan berguna memunculkan pemikiran alternatif diluar pemikiran yang mainstream yang diharapkan mampu membebaskan perempuan dari opresi yang dialaminya.

\section{Perspektif Feminis dan Pemikiran Politik Perempuan NU}

Feminisme merupakan ideologi pembebasan perempuan karena yang melekat dalam semua pendekatannya adalah keyakinan bahwa perempuan mengalami ketidakdilan karena jenis kelaminnya (Humm, 2002: 158). Teori feminis mencakup prinsip-prinsip kontekstualitas, prinsip pelaku aktif dan pertanggungjawaban, prinsip sebab akibat dari pemikiran-pemikiran dan prinsip keanekaragaman. Feminis berkaitan dengan pengalaman perempuan, mengungkapkan aspek-aspek kehidupan perempuan yang menggugah kesadaran (Humm, 2002: xii).

Feminisme menawarkan metodologi yang berbeda dengan metodologi yang mainstream. Bagi feminis, pengalaman semua manusia adalah valid dan penting bagi pembangunan ilmu pengetahuan. Sedangkan ilmu pengetahuan patriarkis, yang selama ini diklaim sebagai sesuatu yang ilmiah, berdasarkan pada premis bahwa pengalaman dan pengetahuan laki-laki yang dianggap mewakili keseluruhan manusia, laki-laki dan perempuan, dan versi pengetahuan yang diproduksi bisa diterapkan untuk semua orang (Spender, 1985: 5-6). Metodologi feminis berfokus pada perempuan dan posisinya di masyarakat, sedangkan metodologi lain berfokus kepada laki-laki. Penelitian feminis melihat realitas dari sudut pandang perempuan, dan menolak gagasan yang menyamakan laki-laki dan maskulinitas sebagai hal yang 'universal', dengan tidak lagi menempatkan laki-laki sebagai sentral (Spender, 1985: 67). Penelitian feminis menuntun peneliti untuk menghindari pelanggaran standar etika, dimana biasanya perempuan mengalami penindasan dan diskriminasi dalam proses penelitian, seperti penggunaan bahasa-bahasa seksisme, intervensi dalam kehidupan responden, juga upaya menyembunyikan informasi dari subjek perempuan (Cook \& Fonow, 1990). Penelitian feminis menyertakan peneliti sebagai seorang pribadi dengan latar belakang pengetahuan dan subjektivitasnya, dimana peneliti membangun hubungan dialektik dengan orang-orang yang diteliti (Reinharz, 2005: 336). Feminisme penting dan berguna untuk mengidentifikasi dan memahami kemunculan pemikiran politik perempuan NU alternatif dari sudut pandang perempuan. Standar etika dalam metodologi feminis membantu untuk menjaga sensitivitas gender dalam proses penelitian.

Pendekatan feminisme merupakan suatu cara pandang yang didalamnya terdapat berbagai paham yang berbeda-beda, namun semua menggunakan gender yang didalamnya terdapat relasi kekuasaan sebagai kategori analisisnya (Stean and Pettiford, 2009: 325). Meskipun banyak aliran feminisme, penulis hanya akan membahas aliran-aliran feminis yang fokus kepada makrokosmos dalam menjelaskan pemikirannya, yakni feminis Liberal, feminis Radikal, feminis Marxis, dan feminis Sosialis. Rosemary Putnam Tong (2008) menyatakan bahwa sebagian besar aliran feminis yang ada saat ini merupakan reaksi 
terhadap feminis liberal. Sepakat dengan hal tersebut, saya mengawali pembahasan tentang feminisme dengan mengkritisi feminis liberal.

\section{Feminis Liberal}

Feminis Liberal memberikan perhatian utama kepada individu, rasionalitas, pembedaan publik dan privat, dan reformasi institusi (Marsh and Stoker, 2012: 131). Perempuan dan laki-laki memiliki tingkat rasionalitas dan nalar yang sama, oleh karenanya perempuan dan laki-laki seharusnya diperlakukan dengan cara yang sama. Perempuan yang berada pada posisi yang tidak sama dengan laki-laki, tidak memiliki hak yang sama sebagai warga negara, berdampak kepada diskriminasi, marginalisasi, kekerasan, subordinasi. Jika perempuan mendapatkan pendidikan, kedudukan, kesempaatan politik, serta penjaminan hak perempuan sebagai hak asasi manusia yang sama antara laki-laki dan perempuan, maka perempuan tidak akan tersubordinasi lagi. Feminis liberal percaya bahwa kesetaraan lakilaki dan perempuan serta partisipasi politik yang sama dan dijamin secara legal oleh sistem, akan mampu membebaskan perempuan dari ketertindasan (McLaren, 2002: 6).

Feminis liberal cenderung memakai kerangka yang telah ada tentang institusi pemerintah. Negara dapat difungsikan sebagai institusi yang bisa memperbaiki kehidupan perempuan dengan menjamin hak-haknya secara sama sebagai manusia, melalui aturan dan perangkat hukum yang adil dan tidak bias gender. Dengan menggunakan standar maskulinitas sebagai sesuatu yang positif dan sebagai prasyarat utama untuk memasuki wilayah publik, feminis liberal nampak elitis, karena hanya perempuan yang telah mencapai standar itulah yang bisa mendapatkan kesetaraan (Marsh dan Stoker, 2012: 131).

Elstain mencatat kegagalan feminis liberal yang tidak bisa menyelesaikan dualisme hierarki ranah publik dan ranah privat.
Ranah publik dianggap lebih baik dan lebih berharga dibandingkan dengan ranah privat. Sehingga untuk menjadi berharga, maka ranah privat disetarakan dengan ranah publik, dengan hegemoni maskulinitas. Hal ini akhirnya memunculkan gugatan dari kalangan perempuan sendiri yang merasa kecewa dengan tidak diakuinya keberadaan perempuan dengan femininitasnya di ruang publik, dan suara perempuan juga tidak serta merta diakui sebagai aksi politik (Lee, 2007: 170).

Feminis Liberal menjadi jalan yang membebaskan perempuan-perempuan dari kelompok menengah keatas. Perempuan dengan tingkat pendidikan tinggi, kemampuan life skill tinggi, kemampuan ekonomi tertentu, juga kemandirian yang membuatnya mampu bersaing dengan laki-laki di dunia yang maskulin. Namun demikian hal ini tidak mengubah kondisi perempuan tingkat bawah yang tidak mampu mengakses sumber-sumber ekonomi, tingkat pendidikan rendah dan kelompok perempuan yang tersubordinasi dalam keluarga. Feminis Liberal yang memfokuskan diri pada upaya perbaikan institusi formal dan legal, tidak akan bisa mengungkapkan bahwa perempuan memiliki cara pandang yang berbeda karena pengalaman hidup dan ketertindasan yang dialaminya. Demikian pula dengan penekanan kaum feminis liberal kepada partisipasi perempuan dalam institusi-institusi formal dan legal tidak akan menjangkau objek yang akan diteliti oleh peneliti umum.

\section{Feminis Radikal}

Feminis radikal berfokus kepada perbedaan biologis antara laki-laki dan perempuan, terlebih terkait dengan fungsi reproduksi yang memungkinkan perempuan untuk hamil dan melahirkan. Feminis radikal juga memiliki perhatian khusus terhadap perkembangan dan keberadaan bahasa seksisme. Bahasa yang dikonstruksi oleh lakilaki mencerminkan pengalaman laki-laki, 
oleh karenanya perempuan perlu kata baru bahkan bahasa sendiri untuk mengungkapkan pengalaman hidupnya yang berbeda dari laki-laki. Mereka percaya bahasa bukan hanya mendeskripsikan, tetapi mengkreasi realitas. Feminis radikal percaya bahwa transformasi radikal terhadap institusi politik, hukum, ekonomi, sosial, budaya, bahkan medis diperlukan untuk membebaskan perempuan dari penindasan. Feminis radikal percaya bahwa kekuatan patriarki sebenarnya bukan terletak pada institusi politik dan institusi legal lainnya. Dominasi laki-laki atas perempuan bukan melalui area politik hukum dan ekonomi, tetapi melalui berbagai aspek kehidupan, termasuk melalui konstruksi pengetahuan (McLaren, 2002: 7-8).

Feminis radikal memperluas gagasan tentang ruang lingkup politik sampai ke situs-situs kekuasaan diluar arena politik formal dan lembaga-lembaga kunci di ranah publik seperti negara, hingga menjangkau kehidupan keluarga dan seksualitas sebagai situs ketidaksetaraan gender dan situs konstruksi identitas gender. Rosemari Putnam Tong mengkategorikan feminis radikal menjadi dua kelompok, yaitu feminis radikal libertarian dan feminis radikal kultural. Pengkategorian yang dibuat oleh Tong merujuk dari karya Ann Ferguson yang mengulas secara mendalam perbedaan diantara kedua kelompok feminis yang disebutnya sebagai libertarian dan radikal. Kedua kelompok sama-sama melihat adanya opresi dalam setiap hubungan antara laki-laki dan perempuan. Feminis radikal libertarian menganggap represi berasal dari norma seksualitas patriarki yang merepresi hasrat dan kenikmatan seksual semua orang, dengan memberikan stigma-stigma. Sedangkan feminis radikal kultural menganggap hubungan heteroseksual dihegemoni ideologi objektivikasi seksual, dimana laki-laki sebagai subjek dan perempuan sebagai objek, yang mendukung kekerasan seksual laki-laki terhadap perempuan. Perbedaan diantara keduanya nampak pada solusi yang ditawarkan, dimana kelompok libertarian memilih untuk mendapatkan kendali atas seksualitas dan kebertubuhannya dengan menggugat stigma dan norma yang membatasi perempuan untuk mendapatkan kepuasan dan kenikmatan seksual dengan cara apapun, termasuk dengan berhubungan sesama jenis. Sedangkan feminis radikal kultural, lebih memilih melawan praktek seksual yang mendukung kekerasan seksual oleh laki-laki dan merebut kendali atas seksualitasnya dengan fokus kepada prioritas seksualitas perempuan yang lebih peduli dengan keintiman (Putnam Tong, 2008: 93-94).

Slogan thepersonal is political didengungkan oleh kaum feminis radikal untuk menggugat politik formal yang meminggirkan perempuan. Bagi feminis radikal, masalah personal adalah juga masalah politik. Banyak masalah pribadi yang dialami perempuan sepanjang hidupnya yang bukan merupakan kesalahan perempuan, tetapi dampak dari penindasan yang menimpa perempuan terjadi secara sistematis (Hanisc, 1969). The personal is political digunakan untuk mendesakkan pentingnya melihat pengalaman sehari-hari perempuan sebagai subjek materi politik, juga sebagai tindakan politik. Perempuan dapat mengorganisir diri dengan membentuk kelompok-kelompok untuk diskusi yang dapat memunculkan peningkatan kesadaran perempuan untuk berbagi pengalaman dan membangun analisis politik terhadap pengalaman tersebut (Holmes, 2000: 307).

Secara umum, feminis radikal meyakini patriarki yang berkembang di seluruh dunia merupakan sumber opresi yang menimpa perempuan. Patriarki bukanlah determinisme biologis, tetapi merupakan sistem struktur sosial, dan praktik-praktik dimana setiap laki-laki mendominasi, menindas, dan mengeksploitasi perempuan. Patriarki meliputi enam struktur, yaitu (1) mode produksi patriarki, dimana dalam struktur rumah tangga, perempuan 
perempuan adalah kelas yang memproduksi dan laki-laki yang mengambil keuntungan. (2) Patriarki pada pekerjaan dengan upah, melarang perempuan masuk ke dalam jenis pekerjaan yang lebih baik karena menganggap perempuan tidak berkompeten. (3) Patriarki dalam negara, dimana negara bias terhadap kepentingan patriarkis dalam kebijakan dan tindakan. (4) Kekerasan laki-laki, muncul dalam bentuk yang beragam dan secara sistematis dimaafkan dan ditoleransi oleh masyarakat. (5) Patriarki dalam seksualitas, mewajibkan heteroseksualitas, dan standar ganda seksual, yang menempatkan perempuan sebagai objek seks. (6) Patriarki dalam lembaga budaya, menciptakan representasi perempuan dari sudut pandang patriarki dalam arena agama, pendidikan, dan media (Walby, 2014: 28-30).

\section{Feminis Marxis}

Feminismemarxismeyakinibahwakapitalis adalah sumber penindasan bagi perempuan. Opresi terhadap perempuan meningkat seiring dengan perkembangan kapitalisme, industrialisasi dan meningkatnya kepemilikan pribadi (McLaren, 2002:9). Kepemilikan pribadi oleh sejumlah orang memunculkan sistem kelas yang kemudian memunculkan kapitalisme dan imperialisme. Perempuan tertindas karena perempuan dianggap sebagai warga kelas bawah dan dalam keluarga, perempuan sebagai anak atau sebagai istri, dianggap sebagai properti lakilaki yang menjadi ayah atau suaminya. Feminis marxis percaya bahwa institusi tradisional harus diubah secara radikal, terutama struktur ekonomi yang menjadi sumber penindasan. Jika perempuan tidak lagi bergantung secara ekonomi kepada laki-laki, dan tidak dianggap sebagai properti laki-laki, maka ia akan menjadi bebas sebagaimana halnya laki-laki (Tong, 2008: 6). Karena memusatkan perhatian kepada pekerjaan perempuan dikaitkan dengan sistem kapitalis, Feminis Marxis tidak akan mampu menjelaskan isu-isu yang berhubungan langsung dengan kepentingan reproduksi dan seksual perempuan (Tong, 2008: 154).

\section{Feminis Sosialis}

Feminis sosialis menggabungkan ide feminis radikal yang fokus kepada patriarkis dan feminis marxis yang memusatkan perhatian kepada berkembangnya sistem ekonomi kapitalis. Oleh karenanya, menurut mereka, perbaikan kehidupan perempuan hanya akan terjadi jika sistem patriarki dan sistem kapitalis dihancurkan secara bersamaan. Feminis sosialis memfokuskan diri kepada hubungan sosial berbasis materi yang berkontribusi terhadap terbangunnya patriarki. Feminis sosialis berkonsentrasi pada isu tubuh dan seksualitas, seperti reproduksi dan kekerasan terhadap perempuan, yang menurut mereka disebabkan oleh patriarki yang diperkuat sistem ekonomi kapitalis (McLaren, 2002: 11). Pembagian kerja antara laki-laki dan perempuan dalam ranah domestik menempatkan perempuan dalam posisi kerja reproduktif. Hal ini berdampak, ketika perempuan memasuki ranah publik, posisi kerja yang didapatkan juga masih sejalan dengan peran gendernya. Perempuan layak menjadi pendidik, pembantu, dan kerja-kerja lain yang sifatnya melayani dan mendukung profesi yang lebih penting. Kondisi perempuan ditentukan oleh struktur produksi, reproduksi, seksualitas (Mitchell, 1971). Feminis sosialis memiliki kelemahan karena tidak bisa menjawab berbagai kepentingan perempuan yang berada pada posisi yang berbeda karena keragaman ras, kecenderungan seksual, etnik, umur, kondisi fisik maupun kondisi psikologisnya (Tong, 2008: 188)

\section{Upaya Menjelaskan Pemikiran Politik Perempuan NU Non-Mainstream}

Untuk mengidentifikasi pemikiran politik perempuan alternatif, feminis liberal yang menganggap nalar dan rasionalitas perempuan sama dengan laki-laki tidak akan bisa menjelaskan adanya pemikiran 
perempuan yang berbeda karena pengalaman ketertindasan yang dialaminya. Feminis liberal yang menegaskan pemisahan antara ranah publik dan ranah privat, tidak akan mampu menjelaskan kemunculan pemikiran politik perempuan yang bersumber dari permasalahan sehari-hari yang dihadapi perempuan di ruang domestik tanpa membawanya ke ruang publik.

Feminis Marxis bisa digunakan untuk menelusuri kemunculan pemikiran politik perempuan NU alternatif, tetapi hanya bersifat parsial karena penekanannya kepada struktur kelas. Dalam hal ini pemikiran politik perempuan NU alternatif dimaknai sebagai pemikiran yang muncul karena ketertindasan perempuan yang terpinggirkan dalam sistem produksi di ruang publik. Di sisi lain, feminis Marxis tidak bisa menjelaskan kemunculan perempuan NU yang berpartisipasi dalam proses produksi di ruang publik, mandiri secara ekonomi, tetapi tetap teropresi saat berhadapan dengan laki-laki yang menjadi suami, ayah, ataupun kerabat laki-laki yang menjadi pengambil keputusan dalam keluarga.

Feminis sosialis, meskipun melihat secara lebih komprehensif penyebab opresi terhadap perempuan, yakni sistem kapitalis yang dikuatkan dengan patriarki, juga tidak akan bisa membantu menggambarkan pemikiran perempuan NU kelas bawah. Aspek sosio historis seperti kultur, ras, kekerabatan, ditambah dengan kondisi fisik dan psikologis perempuan yang berbeda, yang memunculkan keragaman bentuk opresi terhadap perempuan tidak menjadi pusat perhatian feminis sosialis. Oleh karenanya peneliti akan menggunakan feminis radikal, aliran feminis yang memberikan peluang-peluang bagi perempuan untuk memilih caranya sendiri agar terbebas dari opresi yang dialaminya untuk membantu mengidentifikasi dan menjelaskan kemunculan pemikiran politik perempuan NU alternatif.

Feminisme radikal adalah perspektif yang paling sesuai untuk mengungkap pemikiran politik perempuan NU non mainstream. Pemikiran politik perempuan NU alternatif yang bersumber dari relasi kuasa antara lakilaki dan perempuan di dalam rumah tangga bisa diungkap dengan feminis radikal. Hal ini bisa dijelaskan dengan mengurai relasi kuasa dalam rumah tangga yang diawali dengan subordinasi pemaknaan seksualitas perempuan, dimana perempuan dalam struktur patriarki diharuskan menerima hubungan heteroseksual, yang pada akhirnya menempatkan perempuan hanya sebatas objek seksualitas laki-laki.

Feminisradikaljugamembantumenjelaskan adanya perlawanan-perlawanan yang dilakukan perempuan dengan pemikiran-pemikirannya yang dituangkan dalam bahasa tertentu. Hanya feminis radikal yang mengakui adanya konstruksi pengetahuan yang bisa berdampak kepada penindasan terhadap perempuan. Dengan demikian feminis radikal memungkinkan untuk menggambarkan pemikiran politik perempuan NU alternatif dengan bahasa-bahasa yang berperspektif perempuan untuk menghindari bahasa yang diskriminatif dan seksis dalam pengungkapannya. Feminis radikal membantu menjelaskan adanya perlawanan-perlawanan yang dilakukan perempuan dengan pemikiranpemikirannya yang dituangkan dalam bahasa tersebut.

Hanya feminis radikal yang melihat bahwa kekuatan dominasi laki-laki bukanlah berada pada institusi formal dan legal, tetapi masuk dalam semua segi kehidupan. Opresi yang dialami perempuan NU dalam kehidupan sehari-hari bisa diidentifikasi menggunakan cara berpikir kaum feminis radikal, mengingat opresi yang dialami oleh perempuan NU di tingkat bawah terutama terjadi dalam lingkup rumah tangga. Feminis radikal memperluas gagasan tentang ruang lingkup politik sampai ke situs-situs kekuasaan diluar arena politik formal dan lembaga-lembaga kunci di ranah publik seperti negara, hingga menjangkau kehidupan keluarga dan seksualitas sebagai 
situs ketidaksetaraan gender dan situs konstruksi identitas gender.

\section{Kesimpulan}

Pemikiran politik perempuan NU, baik mainstream maupun non-mainstream menganggap patriarki adalah sumber opresi bagi perempuan, yang masuk ke semua aspek kehidupan perempuan. Perbedaan antara pemikiran politik perempuan mainstream dan non-mainstream terletak pada preskripsi yang diberikan atas permasalahan opresi terhadap perempuan. Preskripsi yang ditawarkan oleh pemikiran non-mainstream adalah dengan cara memaknai ulang relasi antara laki-laki dan perempuan dalam rumah tangga. Pemikiran politik perempuan non-mainstream, terutama yang berkaitan dengan preskripsi terhadap persoalan opresi perempuan, bisa ditemukan dan berkembang melalui forum-forum informal berupa pengajian-pengajian, arisan, dan forum aktivisme perempuan NU tingkat bawah lainnya. Pemikiran non-mainstream muncul sebagai bentuk perlawanan atas opresi yang dialami oleh perempuan NU tingkat bawah atas relasi kuasa yang timpang antara lakilaki dan perempuan, yang berlangsung bukan saja dalam wilayah politik formal, tetapi juga dalam wilayah kehidupan informal. Pemikiran ini sekaligus merupakan perlawanan atas dominasi pemikiran politik perempuan mainstream yang telah mapan.

Feminis radikal, meskipun dianggap sebagai perspektif feminis yang kuno dan seringkali terjebak pada esensialis, bisa menggali permasalahan opresi yang mendasar yang dialami oleh semua perempuan melintasi berbagai latar belakang fisik, psikologis, kelas sosial, bahkan tingkat ekonomi dan pendidikan. Penguasaan seksualitas dan tubuh perempuan dalam ruang publik dan ruang privat bersumber dari patriarki yang dibangun mulai dari institusi-institusi kecil berupa keluarga, sampai pada dominasi yang dilakukan oleh negara patriarkis. Tubuh dan seksualitas perempuan yang dijadikan objek inilah yang dijawab secara jelas oleh perspektif feminis radikal. Feminis radikal juga memberikan ruang bagi perempuan teropresi untuk mencari jalan pembebasan yang dipilih, yakni dengan membebaskan dirinya dari fungsi-fungsi reproduksi yang dianggap menindas, membebaskan diri untuk menikmati seksualitas sesuai dengan pilihan masingmasing, maupun dengan menghargai tubuhnya sendiri dengan fungsi-fungsi reproduksi yang tidak tergantikan dengan fungsi artifisial yang direkayasa patriarki untuk mengasingkan perempuan.

\section{Daftar Pustaka}

Anshor, Maria Ulfah. (2006). Fikih Aborsi, Wacana Penguatan Hak Reproduksi Perempuan. Jakarta: Kompas.

Anshor, Maria Ulfah. (2006). Nalar Politik Perempuan Pesantren. Cirebon: Fahmina Institut.

Munir, Lily Zakiyah. (1999). Memposisikan Kodrat. Bandung: Mizan

Cook, J.A., \& Fonow, M.M. (1990). Knowledge and Women's Interest: Issues of epistemology and methodology in feminist sociological research, in J. M. Nielsen (ed), Feminist Research Methods: Exemplary readings in the Social sciences (pp 69-93), Boulder: Westview Press.

Douglas, Carol Anne. (1990). Love and Politics, Radical Feminist and Lesbian Theories. San Francisco: ISM Press.

Humm, Maggie. (2002). Ensiklopedia Feminisme. Yogyakarta: Fajar Pustaka Baru.

Lee, Theresa Man Ling. (2007). Rethinking the Personal and the Political: Feminist Activism and Civic Engagement. Hypatia: Journal of Feminist Philosophy (Online), Volume 22, No. 4, 2007 (http://www.jstor. org/stable/4640110, diakses 1 November 2014)

Marsh, David dan Stoker, Gerry. (2012). Teori dan Metode dalam Ilmu Politik. Bandung: Nusa Media. 
McLaren, Margaret. (2002). Feminism, Foucault, and Embodied Subjectivity. Albany, NY: Suny Press.

McLaughlin, Janice. (2003). Feminist Social and Political Theory, Contemporary Debate and Dialogue. New York: Palgrave.

Mitchell, Juliet. (1971). Women Estate. New York: Pantheon Books.

Mulia, Siti Musdah. (2005). Muslimah Reformis: Perempuan Baru Keagamaan. Bandung: Mizan.

Mulia, Siti Musdah. (2006). Islam dan Inspirasi Kesetaraan Gender. Jakarta: Kibar Press. . (2007). Islam Menggugat Poligami. Jakarta: Gramedia Pustaka Utama. . (2008). Mепuju Kemandirian Politik Perempuan:Upaya Mengakhiri Depolitisasi Perempuan di Indonesia. Jakarta: Kibar Press.

. (2010). Islam dan Hak Asasi Manusia: Konsep dan Implementasi. Yogyakarta: Naufan Pustaka.

. (2011). Muslimah Sejati:

Menempuh Jalan Islami Meraih Ridha Ilahi. Bandung: Marja.

. (2012). Membangun Surga di

Bumi, Kiat-Kiat Membina Keluarga Ideal dalam Islam. Jakarta: Elex Media Komputindo. (2013). Mereka yang di Atas

Persoalan, Kumpulan Profil dan Wawancara Jurnal Perempuan. Jurnal Perempuan. No. 58.

. (2014). Diskusibuku Muslimah

Reformis, kerjasama Mahasiswa UI dan Megawati Institut, tanggal 12 Nopember 2014, di Jakarta. (http://icrp-online.org/wpcontent/uploads/2014/11/Mengapa-PerluMuslimah-Reformis.pdf)
(2014). Kemuliaan Perempuan

Dalam Islam. Jakarta: Elex Media Komputindo.

Mulia, Siti Musdah., dan Farida, Anik. (2005).

Perempuan dan Politik. Jakarta: Gramedia Pustaka Utama.

Noer, Deliar. (1965). Pengantar ke Pemikiran Politik. Medan: Dwipa.

Nuriyah, Shinta, dkk. (2001). Wajah Baru Relasi Suami-Istri: Telaah Kitab Uqud al-Lujjayn. Yogyakarta: LkiS.

Parawansa, Khofifah Indar. (2006). Mengukur Paradigma Menembus Tradisi: Pemikiran Tentang Keserasian Jender. Jakarta: LP3ES. . (2002). Hambatan terhadap

Partisipasi Politik Perempuan di Indonesia, dalam International IDEA, Perempuan di Parlemen: Bukan Sekedar Jumlah. Jakarta: AMEEPRO.

. (2015). Memimpin Melayani, Pandangan Sosial Politik. Bandung: Nuansa Cendekia.

(2015), NU, Perempuan, Indonesia: Sudut Pandang Islam Tradisional. Bandung: Nuansa Cendekia.

Reinharz, Shulamit. (2005). Metode-Metode Feminis dalam Penelitian Sosial. Jakarta: Women Research Institute.

Spender, Dale. (1985). For The Record: The Meaning and Making of Feminist Knowledge. London: Women Press.

Tong, Rosemarie Putnam. (2008). Feminist Thought, Pengantar paling Komprehensif kepada Arus Utama Pemikiran Feminis. Yogayakarta: Jalasutra.

Walby, Sylvia. (2014). Teorisasi Patriarki.

Yogayakarta: Jalasutra. 